\title{
OPTIMALISASI PENDIDIKAN ASWAJA PADA GENERASI MILENIAL SEBAGAI UPAYA DERADIKALISASI
}

\author{
Su'udin Aziz \\ Institut Agama Islam (IAI) Sunan Giri Bojonegoro \\ e-mail: azizsuudin@sunan-giri.ac.id
}

\begin{abstract}
Radicalism is a increasingly prevalent phenomenon in Indonesia for recent years. Radicalism increasingly developed when 'orde baru' (soeharto's regime) ended. The reform era is expanding space for people to express their feeling, including expressions of diversity. Including indicators of the emergence of radicalism in Indonesia is the birth of religious organizations that often use violent methods in carrying out its mission. Various radical Islamic organizations have various characteristics, variants and also orientations. However, there are similarities between radical Islamic organizations, namely the use of violence that came to be known as terror. Unfortunately almost of groups are dominated by millennial generation. This problem is a concern for the wider community surely.Various efforts to respond radicalism also appears contra ideology between them too. Aswaja education proved be able to prohibit radicalism viruses.

This article will present data from interviews, observations, and literature reviews related to the topic. The arguments which built in this paper are reconstruction and actualisation values which contained in Aswaja can be strongly internalized in person's life, especially millenial generation. The proper aswaja socialization and internalization is trough education. In schools, colleges, and study forums which apply aswaja content; students, college students, and the study participants will have opportunity to have moderate religion understanding and will be far away from radicalism diseases.
\end{abstract}

\section{Keyword: Toleran, Religion, Peace}

\section{A. Pendahuluan}

Fenomena yang semakin marak di negeri Indonesia ini di antaranya adalah radikalisme. Di antara tanda maraknya radikalisme di Indonesia adalah bermunculannya organisasi-organisasi keagamaan yang sering menggunakan cara-cara kekerasan dalam melancarkan misinya. Organisasi Islam radikal memiliki varian, karakteristik dan orientasi yang beraneka ragam. Meski demikian, ada kesamaan di antara organisasi- 
organisasi Islam radikal, yakni penggunaan jalan kekerasan yang kemudian dikenal dengan istilah teror.

Banyak faktor yang memicu tindakan terorisme di era modern saat ini, seperti faktor politik, ekonomi, ideologi, dan akibat Kolonialisme Modern dan Globalisasi ${ }^{1}$. Berdasarkan laporan Patterns Of Global Terorism 2000, yang dikeluarkan oleh pemerintah Amerika Serikat, gerakan terorisme yang bermotif agama dan Ideologi merupakan faktor utama. Mengapa Persoalan terorisme berdasarkan agama dan Ideologi menjadi sangat populer? Hal itu karena agama merupakan salah satu dari sekian banyak identitas yang mampu membuat sentimen personal bahkan komunal sehingga masyarakat bersedia berbuat apa saja atas nama agama. Di sinilah persoalan ideologi agama sering menjadi titik tolak dalam menggunakan cara-cara kekerasan dalam menghadapi realitas. ${ }^{2}$

Gerakan Islam radikal yang tumbuh secara masif mendapatkan beragam respons dari banyak kalangan. Ada yang merespons positif dengan mendukung, ada yang merespons reaktif-emosional, ada yang merespons kreatif, dan ada pula yang merespons secara anarkis. Sampai saat ini respons yang diberikan belum relatif memperlambat atau menghentikan tindakan radikal bahkan cenderung menambah angka pelaku terorisme atas nama agama.

Masa depan Islam yang ada di Nusantara ini sebenarnya terancam oleh eksistensi organisasi Islam radikal. Hal itu dikarenakan tipologi Islam Nusantara adalah ramah, toleran dan humanis. Sejarah pertumbuhan Islam di Nusantara selama ratusan tahun berawal dari era walisongo menunjukkan bahwa Islam yang ramah, toleran, humanis dan damai relative cocok dan diterima oleh masyarakat Indonesia. Sementara Islam radikal sebenarnya merupakan model Islam yang tidak mempunyai harapan untuk bertahan di masa depan. Salah satu sebab yang menjadikan Islam model ini tidak punya harapan adalah karena karakter kelompok

1 Peter Beyer, Religion and Globalization (New York: Sage Publication, 2002), h. 8

2 Penjelasan mengenai teror yang dilakukan atas nama agama dapat diperiksa secara detail dalam buku Mark Juergensmeyer, Terror in the Mind of God (California, USA: Springer, 2002), h. 221. 
Islam radikal yang menafikan nilai-nilai kultur Indonesia. ${ }^{3}$ Karena tidak menghargai terhadap nilai-nilai kultur Indonesia maka Islam radikal seringkali menggunakan cara-cara yang bertentangan dengan realitas budaya Nusantara yang telah mengakar kuat di masyarakat. walhasil tidak jarang dari kelompok Islam radikal menggunakan kekerasan dalam melaksanakan aktivitas keagamaannya. Cara kekerasan yang mereka tempuh acapkali memicu timbulnya kekerasan demi kekerasan selanjutnya. Jika Islam radikal terus mengembangkan sayap ke banyak bidang kehidupan maka kehidupan damai dan toleran akan semakin sangat sulit untuk kita temukan.

Organisasi Islam arus utama sangat perlu memberikan sebuah respons aktifkreatif-konstruktif terhadap pelabagai permasalahan ini agar virus Islam radikal tidak kian menyebar dan mengakar pengaruhnya. Infiltrasi gerakan kelompok Islam radikal harus dilakukan secara massif khususnya terhadap generasi milenial (lahir pada tahun 2000-an). Pilihan terhadap generasi milenial ini dipandang cukup strategis karena pada generasi ini pada umumnya belum memiliki pengalaman dan pemahaman yang matang dalam urusan keagamaan. Generasi ini seringkali sangat mudah didoktrin dengan ideologi dan paham keagamaan tertentu kemudian direkrut ke dalam kelompok tersebut dan siap memperjuangkan visi misi kelompoknya tanpa kompensasi apapun. Jika benih-benih radikalisme tidak diantisipasi sejak dini oleh banyak kalangan maka sudah barang tentu paham Islam radikal akan terus meracuni otak para generasi milenial dan berkembang secara luas, implikasinya, semakin kecil peluang membangun harmoni sosial dalam masyarakat Indonesia yang notabene multikultur, kekerasan dan intoleransipun akan semakin banyak kita jumpai.

Satu dari sekian upaya yang dapat dilakukan oleh banyak kalangan untuk mencegah paham Islam radikal adalah melalui pelajaran, mata kuliah dan kajian Aswaja secara optimal. Pelajaran atau yang sistematis dan terstruktur adalah media

3 Wasid Mansyur, Menegaskan Islam Indonesia, Belajar dari Tradisi Pesantren dan NU, (Surabaya: Pustaka Idea, 2014), h. 41 
yang memungkinkan peserta didik dan mahasiswa untuk mengenal memahami apa yang dimaksud Islam radikal, karakteristiknya, bahayanya dan berbagai aspek secara menyeluruh. Mata kuliah yang berpotensi dapat mencegah dari paham radikalisasi adalah mata kuliah Aswaja. Mata kuliah Aswaja adalah mata kuliah wajib muatan institusi di Isntitut Agama Islam (IAI) Sunan Giri Bojonegoro. IAI sunan Giri Bojonegoro merupakan perguruan tinggi di bawah naungan Lembaga Perguruan Tinggi Nahdlatul Ulama (LPTNU) Pengurus Besar Nahdlatul Ulama (PBNU).

Mata kuliah Aswaja (Ahl al-Sunnah Wa-l Jamaah) memiliki potensi yang sangat besar untuk menjadi counter terhadap derasnya penyebaran paham radikal karena mata kuliah ini merupakan sistem teologi yang moderat. Mata kuliah Aswaja yang disampaikan di bangku perkuliahan dapat menjadi media untuk membangun pemahaman Islam yang inklusif, toleran, dan moderat. Pengetahuan dan pemahan inilah yang kemudian menjadi modal untuk bersikap kritis dalam menghadapi dinamika sosial keagamaan yang semakin kompleks dewasa ini. Dalam tulisin ini setidaknya penulis akan membahas tiga hal, yakni (1) nilai-nilai dasar yang terdapat dalam Aswaja, (2) signifikansi Aswaja dalam konteks dewasa ini, dan (3) strategi internalisasi Aswaja di IAI Sunan Giri Bojonegoro

\section{B. Deradikalisasi Melalui Pendidikan}

Secara umum gerakan Islam radikal menjadi sebuah ancaman bagi bangsa ini. Jalan kekerasan yang mereka pilih baik dalam bentuk aktual, sistemik, ataupun simbolik selalu menjadi teror mental yang mencekam bagi kelompok Islam lain. Karakter pemikiran kelompok Islam radikal adalah meyakini bahwa paham keagamaan yag mereka pegang selama ini adalah kebenaran yang mutlak tidak bisa didialogkan. Dampak dari pemikiran semacam ini tidak adanya ruang dialog konstriktif bagi kelompok lain untuk mendiskusikan pelbagai persoalan keagamaan kehidupan. Indonesia merupakan negara yang mempunyai karakteristik plural, 
bahkan negara yang masyarakatnya paling plural. ${ }^{4}$ Adalah sebuah penilaian yang wajar dan tentunya tidak belebihan jika Indonesia dikatakan negara yang multietnis, multi-iman dan multi ekspresi kultural politik. Karena itulah, sebagaimana dijelaskan Ma' arif, keanekaragaman yang dimiliki oleh Indonesia ini harus dikelola secara baik, cerdas dan jujur. Jika pengelolaannya mampu dilaksanakan secara optimal maka akan berubah menjadi kekayaan kultural yang dahsyat. ${ }^{5}$ Kekayaan kultural yang begitu dahsyat akan mudah hancur di tangan beberapa orang atau kelompok Islam radikal. Gagasan dan paham keagamaan yang mereka kampanyekan tidak untuk didiskusikan atau diperdebatkan. Mereka juga enggan dan tidak mau menerima adanya kebenaran selain dari kelompok mereka. Jika ada yang tidak menerima atas apa yang mereka usung, mereka menggunakan segala cara agar dapat diterima. Tidak jarang dari kelompok Islam radikal menggunakan istilah yang menyesatkan untuk menuduh kelompok lain. Kafir merupakan istilah yang mudah disematkan, padahal yang dianggap kafir ' wajib' diperangi sampai darah penghabisan. ${ }^{6}$

Munculnya kelompok Islam radikal sebagai sebuah tantangan besar bagi bangsa ini sebenarnya juga berhadapan dengan utopia. Visi utama kelompok Islam radikal adalah purifikasi ajaran Islam. Menurut Kato, pemurnian agama sebagaimana yang mereka klaim sebenarnya khayalan belaka. ${ }^{7}$ Hal ini semata-mata disebabkan karena purifikasi yang selama ini mereka klaim sesungguhnya adalah sebuah interpretasi dan pemahaman keagamaan dari sebuah interpretasisebagaimana kita tahu-hasilnya akan bersifat relatif. Upaya yang sangat efektif dalam rangka membendung arus radikalisme salah satunya dengan media pendidikan. Kemajuan yang bisa dicapai oleh manusia itu sifatnya tidak parsial,

4 Abdul 'Dubbun' Hakim, " Islam, Inklusivisme, dan Kosmopolitanisme," dalam Abdul Halim (ed.), Menembus Batas Tradisi Menuju Masa Depan yang Membebaskan, Refleksi atas Pemikiran Nurcholish Madjid, (Jakarta: Kompas dan Universitas Paramadina, 2006), h. 19.

5 Ahmad Syafi' i Ma' arif, Islam dalam Bingkai Keindonesiaan dan Kemanusiaan: Sebuah Refleksi Sejarah, (Bandung: Mizan bekerja sama dengan Ma’ arif Institute Jakarta, 2009), h. 246

6 Zuly Qodir, Radikalisme Agama di Indonesia, (Yogyakarta: Pustaka Pelajar, 2014), h. 41.

7 Hisanori Kato, Kangen Indonesia, Indonesia di Mata Orang Jepang, cet. III, (Jakarta: Kompas, 2013) 
melainkan komprehensif. Titik pijak kemajuan tersebut adalah adanya kepedulian yang tinggi terhadap dunia pendidikan. Pendidikan menjadi media penting untuk mengantarkan seseorang memiliki karakter yang baik. Melalui pendidikan, seseorang akan mendapatkan pengetahuan dan keahlian yang tinggi. Semua itu mungkin untuk diperoleh malalui kemampuan intelektual. Pada saat yang sama, pengetahuan dan kemampuan yang dimiliki tersebut juga selaras dengan kebutuhan bangsa. ${ }^{8}$ Pendidikan terbukti mampu menjadikan seseorang mempunyai pengetahuan, wawasan, pengalaman dan ketrampilan hidup yang memadahi. Apa yang dihasilkan dari sebuah pendidikan dapat menjadi modal penting dalam menjalaani kehidupan, bahkan, pendidikan sesungguhnya merupakan tabungan kekayaan di masa depan, baik kekayaan finansial, intelektual, sosial maupun kultural $^{9}$. Hal yang dapat mewujudkan keberhasilan tujuan tersebut tidak hanya ditentukan oleh faktor anak didik semata. Ada banyak faktor yang saling berhubungan, secara subsstansial proses pendidikan sangat berpengaruh dengan sistem pendidikan secara keseluruhan. Berangkat dari pemahaman tentang signifikasi pendidikan tersebut maka pendidikan perlu dikonsentrasikan untuk menghasilkan anak didik yang memiliki kemampuan andal. Kemampuan ini bisa diperoleh melalui usaha-usaha pemberdayaan sumber daya manusia secara maksimal. Usaha maksimal ini diharapkan mampu melahirkan manusia yang terpelajar dan berbudaya (educated and civilized human being) yang dapat mengangkat kehormatan atau martabatnya. ${ }^{10}$

Sayid Ahmad Khan, seorang tokoh besar India adalah satu dari sekian tokoh dunia yang menyadari akan signifikansi pendidikan. Begitu pentingnya makna pendidikan, sampai beliau mengatakan, "Didiklah, didiklah, didiklah! Semua penyakit sosial politik di India bisa diobati dengan cara ini. Obatilah akarnya dan

8 Nik Mustapha Hj. Nik Hassan, "Civil Society for Sustainable Economic Development," dalam Syed Othman Alhabshi and Nik Mustapha Nik Hassan (eds.), Islam Knowledge and Ethics: a Partinent Culture for Managing Organizations, (Kuala Lumpur: Institute of Islamic Understanding Malaysia (IKIM), 1998), h. 184.

9 Mujamil Qomar, Menggagas Pendidikan Islam, (Bandung: Remaja Rosdakarya, 2014), h. 128

10 Mujamil Qomar, Menggagas Pendidikan Islam, h. 130. 
pohonnya akan subur. ${ }^{11}$ Pesan dari tokoh tersebut memberikan gambaran betapa pentingnya pendiidkan dalam kehidupan ini. Pendidikan diyakini merupakan sarana penting untuk mengatasi berbagai macam persoalan kehidupan. Manusia yang merupakan produk berpendidikan akan mampu berkontribusi baik teori, strategi maupun kontribusi dalam bentuk lain dalam rangka menyelesaikan pelbagai problem yang sedang berkembang di tengah-tengah kehidupan. Selain itu manusia yang terdidik juga mempunyai potensi besar untuk membangun kemajuan kehidupan dalam skala lebih luas. Berangkat dari pemikiran seperti inilah maka dipandang sangat perlu melakukan sepuah upaya sistematis melalui jalur pendidikan secara optimal guna mencegah penyebaran paham radikal yang sedang berkembang dan meresahkan banyak kalangan. Suburnya perkembangan radikalisme membutuhkan keterlibatan banyak kalangan, mulai negara, agamawan, hingga masyarakat agar langkah-langkah konkrit kelompok radikal dapat pelanpelan dieliminir perkembangannya.

\section{Nilai-Nilai Yang Terkandung Dalam Ajaran Aswaja}

Nilai-nilai yang terkandung dalam ajaran Aswaja menjadi signifikan untuk dimunculkan dan diaktualisasikan di tengah arus radikalisme yang semakin berkembang dan menguat. Nilai-nilai ini berpotensi dapat dijadikan counter untuk membendung paham radikal. Melalui rekontruksi nilai-nilai aswaja yang kemudian disosialisasikan secara massif-di antaranya melalui jalur pendidikan-diharapkan dapat memberikan pemahaman masyarakat terhadap signifikansi ajaran Islam moderat dan Islam yang rahmah penuh dengan kasih sayang.

Ajaran Islam tidak identik dengan kekerasan, justru sebaliknya, cara-cara damai yang digunakan oleh Islamlah yang membuat Islam bisa hadir dan menjadi bagian yang tidak terpisahkan dari kehidupan Indonesia selama ratusan tahun. Sebab itulah Islam tidak pernah setuju dengan model-model ajaran akidah yang diusung oleh kelompok Islam radikal. Ajaran Aswaja sangat menentang respons dan 
penyelesaian terhadap persoalan melalui jalan kekerasan, pemaksaan, apalagi disertai perusakan. Aswaja juga menolak terhadap eksistensi kelompok-kelompok yang menutup diri golongan mayoritas kaum muslimin. ${ }^{12}$ Banyak pengalaman sejarah Islam Indonesia yang mengedepankan interaksi sosial yang harmonis perlu untuk diperhatikan agar masa depan Islam Indonesia tidak terperosok dalam lubang konflik.

Transformasi kehidupan yang sangat cepat menuntut adanya rekontruksi terhadap aswaja. Tanpa melakukan rekontruksi dikhawatirkan Aswaja akan kehilangan relevansi dan aktualitas. Lebih jauh, umat Islam-terutama generasi milenial- tidak lagi mengenal dan memahami ajaran Islam moderat sebagaimana yang diusung oleh Aswaja. Akan lebih parah jika mereka kemudian ikut bergabung dan menjadi aktivis kelompok Islam radikal. Paradigma pemikiran Aswaja bertumpu pada sumber ajaran Islam; al-Qur'an, al-Sunnah, al-Ijma', dan Qiyas. Sementara pada tataran praktik, umat Islam yang menganut Aswaja mengikuti produk pemikiran ulama di masa lalu. Ada tiga pilar inti yang menandai karakteristik Aswaja, yaitu mengikuti paham al-Asy' ari dan al-Maturidi dalam bidang teologi, mengikuti salah satu dari empat imam mazhab (Hanafi, Maliki, Syafi'i, dan Hanbali) dalam bidang Fiqih, dan mengikuti Imam Junaid al-Baghdadi dan Imam al-Ghazali dalam bidang tasawuf. ${ }^{13}$

Aswaja juga memiliki nilai-nilai menarik selain tiga pilar di atas. Nilai menarik tersebut pertama, tawassuth (moderat). Menurut Kamus Besar Bahasa Indonesia (KBBI), moderat mempunyai dua arti, yakni (1) selalu menghindarkan perilaku atau pengungkapan yang ekstrem, (2) berkecenderungan ke arah dimensi atau jalan tengah. ${ }^{14}$ Pemikiran moderat sangat penting karena dapat direkontruksi menjadi semangat untuk menjaga perdamaian, selain itu berfikir moderat juga

12 Masyhudi Muchtar, dkk., Aswaja An-Nahdliyah, Ajaran Ahlussunnah wa al-Jama' ah yang Berlaku di Lingkungan Nahdlatul Ulama, (Surabaya: Khalista dan LTN NU Jawa Timur, 2007), h. 18.

13 M. Masyhur Amin, NU dan Ijtihad Politik Kenegaraannya, (Yogyakarta: Al-Amin Press, 1996), h. 80-85.

14 Departemen Pendidikan dan Kebudayaan, Kamus Besar Bahasa Indonesia, cet. III, (Jakarta: Balai Pustaka, 1990), h. 
menjadi modal penting untuk mengakomodasi berbagai kepentingan yang ada serta mencari solusi yang terbaik atas berbagai pertentangan yang sedang terjadi. Kedua, tawazun (berimbang). Maksud dari berimbang dalam konteks ini sebuah sikap berimabang dan harmonis dalam mengintegrasikan dan mensinergikan dalil-dalil untuk memproduk sebuah keputusan yang bijak dan maslahat untuk umat. Tawazun merupakan manifestasi dari sikap keberagaman yang anti terhadap sikap ekstrem. Kelompok Islam radikal sringkali disebut kelompok ekstrem lantaran kurang-bahkan tidak-menghargai terhadap perbedaan pendapat dan enggan mengakomodasi kekayaan khazanah kehidupan.

Ketiga, tasamuh (toleransi) yang besar terhadap pluralisme pikiran. Aneka pikiran yang muncul dan tumbuh di tengah masyarakat muslim adlah sebuah keniscayaan dan selayaknya mendapatkan pengakuan yang apresiatif. Sikap terbuka yang demikian lebar untuk menerima segala jenis perbedaan pendapat menjadikan Aswaja memiliki kemapuan untuk meredam pelbagai konflik internal di tubuh umat Islam. Dalam diskursus sosial budaya Aswaja banyak melakukan toleransi terhadap tradisi-tradisi yang telah berkembang di masyarakat, tanpa melibatkan diri dalam substansinya, bahkan tetap berusaha untuk mengarahkannya. Formalisme dalam aspek-aspek kebudayaan dalam Aswaja tidaklah memiliki signifikansi yang kuat. Sikap toleran Aswaja telah memberikan makna khusus dalam hubungannya dengan dimensi kemanusiaan yang luas. ${ }^{15}$

Nilai-nilai tersebut di atas yang bisa menjadikan Islam sebagai agama yang mampu berdialektika secara dinamisdengan budaya lokal. Institut Agama Islam (IAI) Sunan Giri Bojonegoro sebagai perguruan tinggi yang berada di bawah naungan Lembaga Perguruan Tinggi NU, ${ }^{16}$ adalah salah satu perguruan tinggi yang mewajibkan mata kuliah Aswaja kepada mahasiswa di semester satu dan dua sebagai upaya menanamkan nilai-nilai Aswaja pada generasi milenial. Pilihan strategis yang akomodatif terhadap budaya lokal ini juga dikembangkan oleh

15 Husein Muhammad, " Memahami Sejarah Ahlus Sunnah wal-Jama' ah yang Toleran dan Anti Ekstrem," dalam Imam Baehaqi (ed.), Kontroversi Aswaja, Aula Perdebatan dan Reinterpretasi, (Yogyakarta: LKiS, 2000), h. 37-41

16 Wawancara dengan M. Jauharul Maarif, Rektor IAI Sunan Giri, Senin, 01 Oktober 2018. 
banyak tokoh NU, di antaranya KH. Achmad Shiddiq. Menurut beliau agama Islam itu berwatak fitri. Maksud dari berwatak fitri adalah sesuai dengan hati nurani, kemampuan dan kebutuhan manusia. Karena fitri ia belum dipengaruhi hawa nafsu. Agama Islam datang tidka untuk menghapuskan segala yang sudah ada dan menolak segala hal yang datang dari luar. Berbagai aspek dalam kehidupan yang sesuai dengan ajaran Islam diteruskan dan dikembangkan, sedangkan yang bertentangan dengan Islam dilarang dan dihapus. ${ }^{17}$ Selain kyai NU ada pula intelektual dari luar jamiyyah NU yang mengakomodasi dan mengapresiasi terhadap tradisi dan budaya lokal, seperti Nurcholis Madjid. Menurut Nurcholis, kedatangan Islam selalu berimplikasi pada terjadinya transformasi sosial menuju kehidupan yang lebih baik. Namun pada saat yang sama, kedatangan Islam tidak mesti disruptif atau bersifat memotong suatu masyarakat dari masa lampaunya, tetapi juga ikut melestarikan aspek yang baik dari masa lampau tersebut dan bisa dipertahankan ujian ajaran universal Islam. ${ }^{18}$

\section{Pentingnya Rekonstruksi Aswaja}

Adalah sesuatu yang sangat mungkin terjadi perubahan pada diri seseorang yang pada awalnya baik dan santun tapi dalam perkembangannya kemudian menjadi aktifis kelompok radikal. Hal itu karena secara sosiologis setiap orang mempunyai peluang untuk mengalami transformasi diri. Aktifitas radikal seseorang akan berimpikasi pada ketakutan masyarakat pada skala luas. Ada banyak faktor yang mempengaruhi transformasi ini, di antaranya karena interaksinya dengan kelompok Islam radikal. Generasi milenial menjadi sasaran empuk karena-salah satunya-kondisi psikologis mereka belum stabil. Psikologis mereka masih mudah goyah lantaran berhadapan dengan dinamika kehidupan yang selalu berubah pula. Kelompok Islam radikal melakukan rekrutmen anggota baru secara intensif. Kampus adalah wilayah prioritas bagi mereka. Mereka masuk ke kampus dengan

17 Lukman Hakim, Perlawanan Islam Kultural: Relasi Asosiatif Pertumbuhan Civil Society dan Doktrin Aswaja NU, (Surabaya: Pustaka Eureka, 2004), h. 104.

18 Nurcholish Madjid, Islam, Doktrin dan Peradaban, (Jakarta: Paramadina, 1992), h. 552 
berbagai cara salah satunya dengan berbagai kegiatan dan terkadang melalui bulletin yang sengaja dibawa oleh mereka. ${ }^{19}$ Aktivis kelompok radikal memang memiliki ikatan ideologis yang sangat kuat dengan ajaran agama yang diyakininya. Mereka tidak pernah patah semangat, berbagai penolakan baik secara halus atau kasar tidak dapat menghentikan langkah usahanya untuk menyebarkan paham keagamaan yang mereka yakini kebenarannya.

Aswaja bukan ajaran normatif yang tidak operasional. Justru pada kondisi seperti ini rekonstruksi Aswaja agar mampu menjadi bagian yang tidak terpisahkan dari kehidupan sehari-hari menjadi sangat penting untuk dilaksankan. Pentingnya rekonstruksi Aswaja disebabkan oleh beberapa alasan. Pertama, Aswaja menjadi identitas teologis yang diperebutkan oleh banyak kelompok Islam. Banyak dari kelompok Islam yang mengkalim kelompok merekalah yang paling sesuai ahlu asSunnah wa-l Jamaah (Aswaja). Permasalahannya bukan kelompok mana yang paling benar dan menganut Aswaja, tapi kelompok mana yang paling mampu menjadikan nilai-nilai Aswaja sebagai instrument untuk melakukan kegiatan sehari-hari. Sebuah klaim akan tidak bermakna jika hanya sebatas klaim dan tidak dibuktikan dengan aktifitas yang selaras dengan ajaran Aswaja. Kedua,substansi Aswaja masih bersifat debatable yang samapai saat ini belum selesai di ruang perdebatan. Hal ini lantaran definisi dan ruang lingkup Aswaja bias dibilang cukup longgar. Meski demikian tetap saja ada karakteristuk yang menonjol pada ajaran Aswaja yang perlu dikemukakan, bukan malah memperbesar titik perbedaan yang kemudian menjadikan ajang perdebatan secara berkepanjangan. Ketiga, Aswaja belum tersosialisasi dan tersusun secara sistematis dalam berbagai aspek kehidupan. Ajaran Aswaja yang dipegang dan dianut oleh warga nahdliyyin sifatnya masih elitis di kalangan terdidik. Masyarakat yang awam biasanya dan seringkali kurang peduli terhadap Aswaja, hal inilah yang menjadikan Aswaja sangat penting untuk direkonstruksi. 
Rekonstruksi Aswaja dapat dimulai dari hal-hal sederhana dan mempunyai pengaruh yang mendalam seperti melalui jalur pendidikan yang diterapkan di kampus IAI Sunan Giri Bojonegoro. Dalam seminggu sekali para mahasiswa mendapatakan mata kuliah Aswaja 1 dan Aswaja 2 selama dua semester. Pengajaran dengan metode ceramah dan diskusi yang sistematis ini merupakan wahana mendasar untuk menanamkan dan menguatkan nilai-nilai Aswaja dalam kehidupan sehari-hari mereka. Strategi semacam ini adalah upaya menjadikan Aswaja sebagai way of life. Setidaknya ada tiga poin penting yang diajarkan dosen Aswaja kepada mahasiswa, yakni bagaimana sejarah munculnya akidah dan paham Aswaja, bagaimana - fikih- amaliyah Aswaja dan dalil-dalilnya, serta bagaimana berpola pikir ala Aswaja. Berakidah Aswaja, beramaliyah Aswaja, dan bermanhajil fikri ala Aswaja, tegas M. Jauharul Maarif. ${ }^{20}$

Dosen Aswaja selama dua semester dibebani mengejawentahkan materi-materi Aswaja dari tataran konsep ke tataran praktis. Materi yang dijelaskan dengan rinci dan detail meliputi implementasi Aswajadalam bidang akidah, syariah (fikih), akhlak, kemasyarakatan, social politik, budaya dan pelabgai bidang lainnya. Dengan demikian harapannya mahasiswa yang didominasi oleh generasi milenial ini mampu memahami dan menguasai karakteristik ajaran Aswaja secara praktis.

\section{E. Strategi Internalisasi Aswaja}

Rencana Program Studi (RPS) Aswaja yang diterapkan kepada mahasiswa selama dua semester disdesain dengan tujuan memberikan pemahaman kepada mahasiswa tentang nilai-nilai Aswaja. Selain secara substansial pengajaran ini dilakukan dalam kerangka penanaman Aswaja secara doktrin, pada level mahasiswa pengajaran juga disertai diskusi bahkan di akhir semester dua juga ada kegiatan simulasi debat Aswaja dengan non Aswaja. Simulasi debat ini bertujuan mengukur sejauh mana para mahasiswa menguasai Aswaja dan mampu memberikan argument ilmiah terhadap kelompok radikal yang seringkali 
menyalahkan amaliyah penganut ajaran Aswaja dengan dalih purifikasi ajaran agama dan intoleran terhadap tradisi-tradisi yang ada di Indonesia.

Kemunculan kelompok Islam radikal sesungguhnya berkelindan dengan berbagai faktor lain. Menurut Muhammad Tholhah Hasan dalam sebuah tulisan yang dikutip oleh Darmadi bahwa munculnya gerakan radikalisme -termasuk Islam radikal- di Indonesia terutama setelah datangnya era reformasi disebabkan variabel oleh ajaran dan pemahaman, peranan media internet (IT), kondisi sosial dan konstalasi politik internasional. ${ }^{21}$ Dosen pengampu mata kuliah Aswaja seringkali memberikan gambaran tentang tantangan yang akan dihadapi oleh mahasiswa kelak ketika terjun langsung ke masyarakat yang beragam. Penjelasan tentang nilainilai Aswaja secara intens dan penekanan signifikansi Aswaja dalam realitasnya cukup efektif bagi mahasiswa dalam rangka memberikan pemahaman tentang Aswaja. Selain itu strategi yang juga perlu untuk dilakukan adalah pelaksanaan amaliyah yang sesuai dengan Aswaja. Pada waktu yang telah terjadwal mahasiswa diajak diskusi seputar dalil amaliyah Aswaja yang berkaitan dengan tradisi Indonesia. Diskusi seputar Aswaja yang belum selesai akan dibawa ke forum di luar kampus, klinik Aswaja. ${ }^{22}$

Setidaknya ada tiga langkah yang dilakukan untuk mengiiplementasikan pendidikan karakter, pertama, keteladanan dari seluruh sivitas akademika kampus. Kedua, pengajaran dilakukan secara konsisten dan kontinyu, dan ketiga, penanaman nilai-nilai karakter utama. Nilai-nilai karakter Aswaja (tawassuth, tawazun, ta' adul, dan tasamuh) disampaikan pada semester dua kemudian mahasiswa diajak untuk mengintegrasikan dengan pendidikan karakter bangsa.

21 Ahmad Darmadi, “ Pondok Pesantren dan Deradikalisasi Islam Indonesia”, Jurnal Millah, Vol. XI, No. 1, Agustus 2011 , h. 236 .

22 Wawancara dengan Ulfa, Dosen mata kuliah Aswaja, 05 Oktober 2018 


\section{F. Kesimpulan}

Berkembangnya Islam radikal menjadi ancaman bagi Indonesia yang kaya akan keragaman. Hal ini harus segera direspons dengan berbagai upaya untuk mencegahnya. Pendidikan adalah salah satu dari sekian media yang cukup strategis untuk deradikalisasi. Mata kuliah Aswaja di IAI Sunan Giri Bojonegoro cukup signifikan memberikan pengaruh terhadap deradikalisasi. Aswaja memiliki nilai substansial yakni, tawassuth (moderat), tawazun (berimbang), dan tasamuh (toleransi). Ketiga nilai ini adalah modal awal yang utama untuk menangkal paham radikal dan membangun paham keagamaan yang tidak ekstrem. Nilai-nilai Aswaja sangat penting untuk direkonstruksi dan disosialisasikan sebagai pedoman hidup sehari-hari. Pedoman ini bersifat fungsional-aplikatif dan memberikan respon aktifkreatif. Strategi pengajaran Aswaja di kampus IAI Sunan Giri Bojonegoro dibuat secara sistematis untuk memberikan pemahaman kepada mahasiswa. Selain di bangku kuliah, mahasiswa juga dibuatkan klinik Aswaja sebagai forum konsultasi terkait Aswaja.

\section{Daftar Pustaka}

Ali, A. Mukti, Alarm Pikiran Islam Modern di India dan Pakistan, Bandung: Mizan,1993.

Amin, M. Masyhur, NU dan Ijtihad Politik Kenegaraannya, Yogyakarta: Al-Amin Press, 1996.

Darmadi, Ahmad, “ Pondok Pesantren dan Deradikalisasi Islam Indonesia” , Jurnal Millah, Vol. XI, No. 1 Agustus 2011.

Departemen Pendidikan dan Kebudayaan, Kamus Besar Bahasa Indonesia, cet. III, Jakarta: Balai Pustaka, 1990.

Hakim, Abdul ' Dubbun' , " Islam, Inklusivisme, dan Kosmopolitanisme", dalam Abdul Halim (ed.), Menembus Batas Tradisi Menuju Masa Depan yang Membebaskan, Refleksi atas Pemikiran Nurcholish Madjid, Jakarta: Kompas dan Universitas Paramadina, 2006.

Hakim, Lukman, Perlawanan Islam Kultural: Relasi Asosiatif Pertumbuhan Civil Society dan Doktrin Aswaja NU, Surabaya: Pustaka Eureka, 2004. 
Hassan, Nik Mustapha Hj. Nik, "Civil Society for Sustainable Economic Development", dalam Syed Othman Alhabshi and Nik Mustapha Nik Hassan (eds.), Islam Knowledge and Ethics: a Partinent Culture for Managing Organizations, Kuala Lumpur: Institute of Islamic Understanding Malaysia (IKIM), 1998.

Kato, Hisanori, Kangen Indonesia, Indonesia di Mata Orang Jepang, cet. III, Jakarta: Kompas, 2013

Ma'arif, Ahmad Syafii, Islam dalam Bingkai Keindonesiaan dan Kemanusiaan: Sebuah Refleksi Sejarah, Bandung: Mizan bekerja sama dengan Ma' arif Institute Jakarta, 2009.

Madjid, Nurcholish, Islam, Doktrin dan Peradaban, Jakarta: Paramadina, 1992.

Mansyur, Wasid, Menegaskan Islam Indonesia, Belajar dari Tradisi Pesantren dan NU, Surabaya: Pustaka Idea, 2014.

Muchtar, Masyhudi, dkk., Aswaja an-Nahdliyah, Ajaran Ahlussunnah wa alJama' ah yang Berlaku di Lingkungan Nahdlatul Ulama, Surabaya: Khalista dan LTN NU Jawa Timur, 2007.

Muhammad, Hussein, "Memahami Sejarah Ahlus Sunnah Waljama' ah yang Toleran dan Anti Ekstrem", dalam Imam Baehaqi (ed.), Kontroversi Aswaja, Aula Perdebatan dan Reinterpretasi, Yogyakarta: LKiS, 2000.

Qodir, Zuly, Radikalisme Agama di Indonesia, Yogyakarta: Pustaka Pelajar, 2014.

Beyer, Peter Religion and Globalization, New York: Sage Publication, 2002 Qomar, Mujamil, Menggagas Pendidikan Islam, Bandung: Remaja Rosdakarya, 2014.

\section{Wawancara:}

M. Jauharul Maarif, Rektor IAI Sunan Giri Bojonegoro, 01 Oktober 2018 Ulfa, Dosen Mata Kuliah Aswaja, 05 Oktober 2018 